Case Report

\title{
Mycosis Fungoides of the Oral Cavity: Fungating Tumor Successfully Treated with Electron Beam Radiation and Maintenance Bexarotene
}

\author{
Juri Bassuner, ${ }^{1}$ Roberto N. Miranda, ${ }^{1}$ Drew A. Emge, ${ }^{2}$ Beau A. DiCicco, ${ }^{3}$ \\ Daniel J. Lewis, ${ }^{2}$ and Madeleine Duvic ${ }^{1}$ \\ ${ }^{1}$ The University of Texas MD Anderson Cancer Center, Houston, TX, USA \\ ${ }^{2}$ Baylor College of Medicine, Houston, TX, USA \\ ${ }^{3}$ University of Texas Medical School at Houston, Houston, TX, USA \\ Correspondence should be addressed to Madeleine Duvic; mduvic@mdanderson.org
}

Received 13 August 2016; Revised 26 October 2016; Accepted 6 November 2016

Academic Editor: Alireza Firooz

Copyright (C) 2016 Juri Bassuner et al. This is an open access article distributed under the Creative Commons Attribution License, which permits unrestricted use, distribution, and reproduction in any medium, provided the original work is properly cited.

Oral involvement in mycosis fungoides is unusual and portends a poor prognosis. The clinical findings of three new cases are described along with a differential diagnosis and review of the literature. For brevity, only one patient is discussed in detail below whereas the other two cases are solely described in table form. The patient had a four-year history of mycosis fungoides before developing an exophytic tongue tumor. He was treated with local electron beam radiation and is disease-free to date while being on maintenance therapy with oral bexarotene. Analysis of the data collected from our review of the literature and the present cases reveal key insights.

\section{Introduction}

One of the most common T-cell lymphomas is mycosis fungoides (MF). It is a malignant, insidious, cutaneous, extranodal non-Hodgkin's lymphoma (NHL) [1]. MF encompasses about $4 \%$ of all lymphoma cases worldwide and has an incidence of 0.36 per 100,00 [2]. The MF disease process has a relatively predictable pattern: in three phases, erythematous or eczematous patches can become infiltrated plaques and cutaneous tumors [1]. Extracutaneous manifestations of MF can involve a wide array of sites, particularly lymph nodes [3].

Oral cavity involvement in MF is rare, found in less than $1 \%$ of patients. Interestingly, autopsy studies suggest up to $13 \%$ involvement [4]. This is thought to be a predictor of poor prognosis. Often, patients have advanced stage disease and the majority have expired shortly after presentation [5-8]. We present a case of oral MF and a review of the literature. Two additional patients with oral MF that presented to our hospital are presented in table form alongside the 45 patients with oral MF found in the literature (Table 2). Key observations are made from analysis of the patients.

\section{Materials and Methods}

We have expanded on our previous case series on oral MF (20) to include three new cases that were selected from the electronic medical records of The University of Texas MD Anderson Cancer Center (UTMDACC). The patients were treated at UTMDACC over periods from 2005 to present (Case 1), 2005 to 2008 (Case 2), and 2015 to present (Case 3).

\section{Case Report}

A 63-year-old white man (Case 1) presented in 2005 with exfoliative erythroderma. He stated that he was diagnosed with a rash localized to his right hand three years earlier. Over the course of one and a half years, his lesions spread widely. On presentation, he had $90 \%$ body surface area (BSA) involvement with a $3: 1$ ratio of plaque to patch. His 
TABLE 1: Differential diagnosis of oral tumors.

\begin{tabular}{|c|c|c|}
\hline Disease & Oral lesion description & Diagnostic clues \\
\hline \multicolumn{3}{|l|}{ Malignancy/premalignancy } \\
\hline Squamous cell papilloma & $\begin{array}{l}\text { Discrete exophytic papillary lesions (verruca): } \\
\text { occur at any intraoral site }\end{array}$ & $\begin{array}{l}\text { History of human immunodeficiency virus } \\
\text { infection; association with cutaneous warts } \\
\text { on fingers }\end{array}$ \\
\hline Squamous cell carcinoma & $\begin{array}{l}\text { Nonhealing ulcers, papules, or plaques: occur } \\
\text { most frequently at the floor of the mouth and } \\
\text { soft palate }\end{array}$ & $\begin{array}{l}\text { History of tobacco and alcohol consumption; } \\
\text { mechanical trauma from ill-fitting dentures }\end{array}$ \\
\hline \multicolumn{3}{|c|}{$\begin{array}{l}\text { Mesenchymal neoplasms and tumor-like } \\
\text { lesions }\end{array}$} \\
\hline Fibrous and vascular overgrowths & Discrete lesions of cheek or tongue & $\begin{array}{l}\text { History of chronic irritation, usually from } \\
\text { some tooth-related cause or chronic } \\
\text { cheek/tongue biting }\end{array}$ \\
\hline Pyogenic granuloma & $\begin{array}{l}\text { Exuberant overgrowths usually at the gingiva } \\
\text { but can occur at any intraoral site }\end{array}$ & $\begin{array}{l}\text { May bleed spontaneously or following } \\
\text { irritation due to extreme vascularity }\end{array}$ \\
\hline \multicolumn{3}{|l|}{ Odontogenic tumors and cysts } \\
\hline Ameloblastoma & $\begin{array}{l}\text { Oral swellings occurring on the mandible that } \\
\text { typically produce multicystic appearance on } \\
\text { radiograph }\end{array}$ & $\begin{array}{l}\text { Painless and slow growing; untreated, may } \\
\text { reach substantial size }\end{array}$ \\
\hline Odontogenic cysts & $\begin{array}{l}\text { Oral swellings arising adjacent to teeth that } \\
\text { usually produce a well-demarcated cyst on } \\
\text { radiograph }\end{array}$ & Painless and slow growing \\
\hline
\end{tabular}

skin exhibited indurated erythematous papular rash that was confluent over the upper and lower extremities with skip areas on the abdomen and relative sparing of the groin.

Flow cytometry revealed $30 \times 10^{9} / \mathrm{L}$ CD 4 cells and $96 \%$ CD4+/CD26- cells. Biopsy of the tumor showed MF with large cell transformation.

The patient received numerous systemic treatments including (1) vorinostat $400 \mathrm{mg}$ daily that improved his pruritus but was accompanied by intolerable side effect of diarrhea and overall lack of response in the skin, (2) forodesine with minor partial response, (3) combined modality with interferon-alpha plus bexarotene and extracorporeal photophoresis, (4) total body skin electron beam radiation that effectively cleared his skin temporarily, and (5) alemtuzumab with which he achieved durable near-complete remission.

After these treatments, roughly four years after initial presentation, the patient presented with a rapidly growing tumor on his tongue measuring $2.0 \times 2.0 \times 2.5 \mathrm{~cm}$ with a central cleft (Figure 1). His skin at that point had $12 \%$ BSA involvement of MF. His tongue biopsy showed a large protruding lesion, lined by squamous mucosa, nonulcerated, composed of a diffuse, dense lymphoid infiltrate that extended deep into underlying skeletal muscle of tongue (Figure 2(a)). On higher magnification, the neoplastic cells were large, with vesicular nuclei and prominent central nucleoli (Figure 2(b)). Approximately 2 atypical mitotic figures per high power field were identified. The large neoplastic cells were strongly and diffusely positive for CD3 (Figure 3(a)) CD4 and CD30 (Figure 3(b)). Approximately $90 \%$ of neoplastic cells expressed the proliferation marker Ki-67. Bone marrow was positive for atypical cells as well. Imaging revealed a $1.3 \mathrm{~cm}$ spiculated lesion in the left upper lobe, which was subsequently biopsied

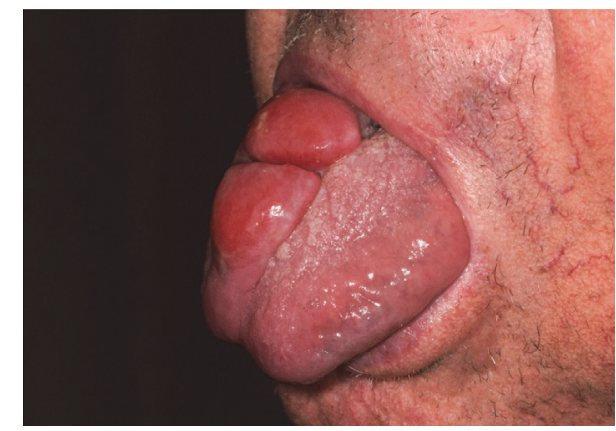

FIgURE 1: Mycosis fungoides tumor of the patient's tongue measuring $2.0 \times 2.0 \times 2.5 \mathrm{~cm}$ with a central cleft prior to treatment. The tumor was responsive to local electron beam radiation and maintenance bexarotene.

and found to be positive for lymphoma. His tumor responded to $22 \mathrm{~Gy}$ of electron beam radiation leaving behind a $3.0 \times$ $1.5 \mathrm{~cm}$ erosion that eventually formed a scar. He was restarted on bexarotene and had an excellent response on the skin. He continues to be disease-free to the time of this writing.

\section{Discussion}

Lymphomatous lesions of the oropharynx in MF are becoming increasingly recognized in the literature. Presentation is heterogeneous, ranging from depressed ulcerations and red or white patches to exuberant outgrowth of tumors. This presents a diagnostic challenge to the uninitiated clinician. The differential diagnosis of various benign and malignant oral lesions is reviewed (Table 1). 


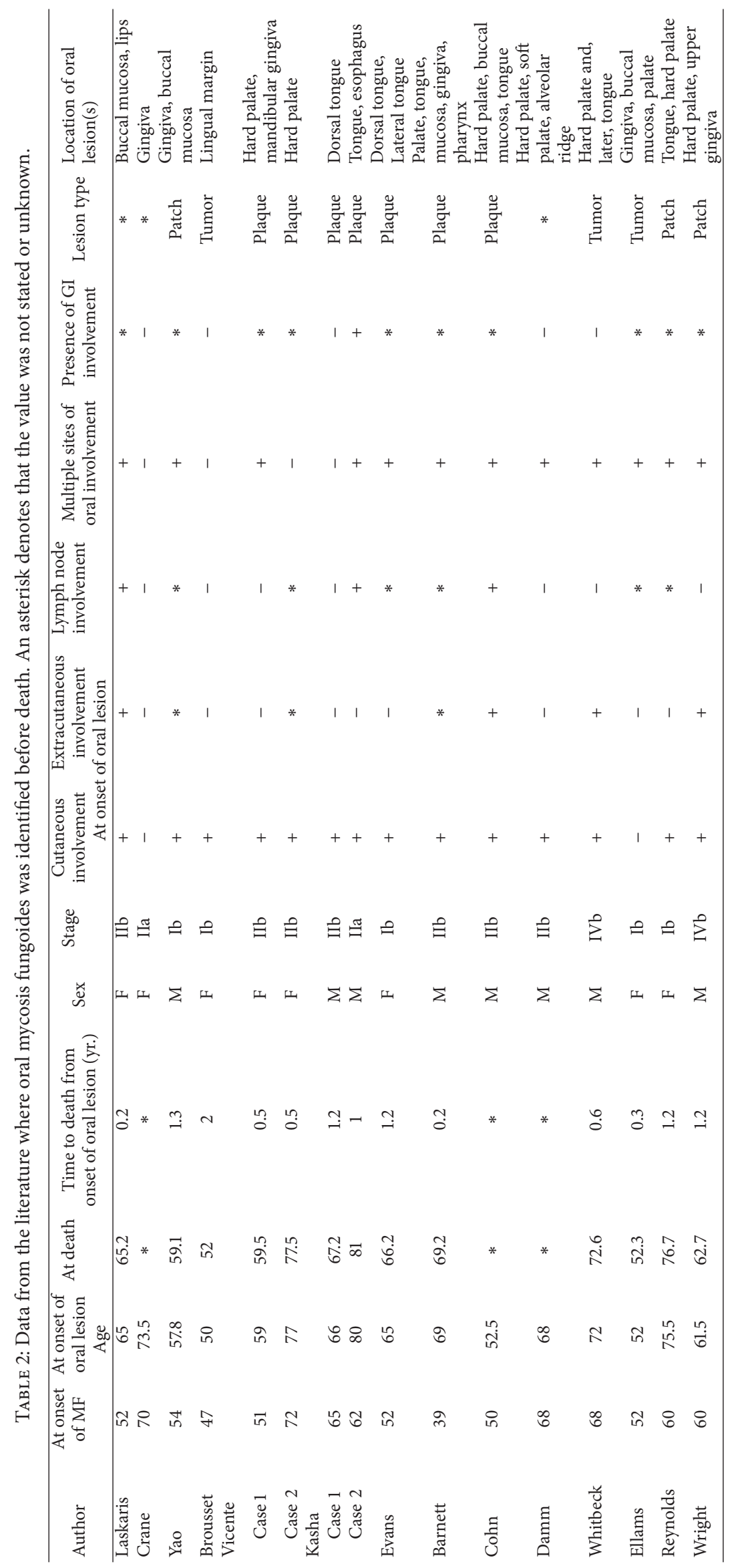




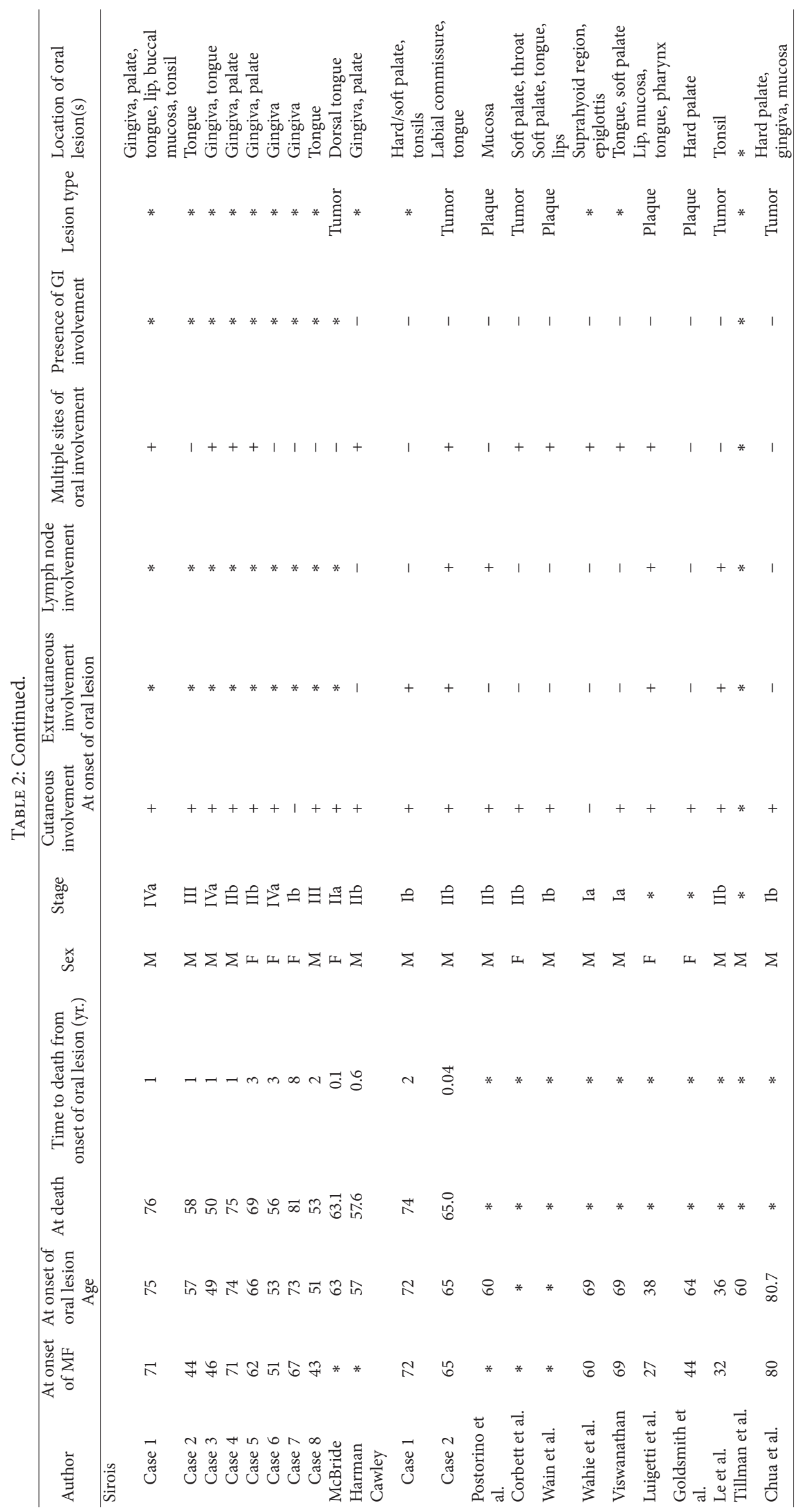




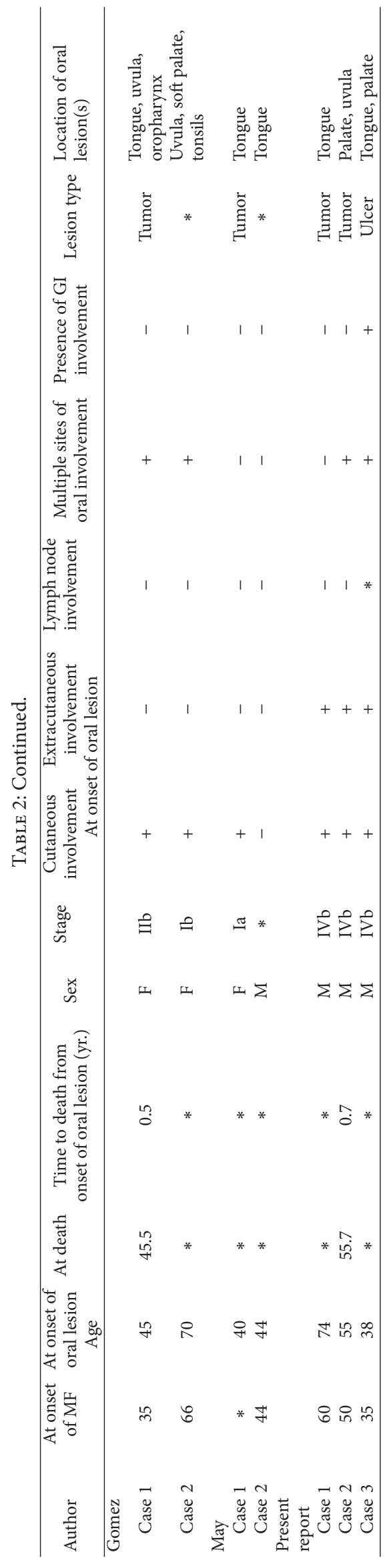




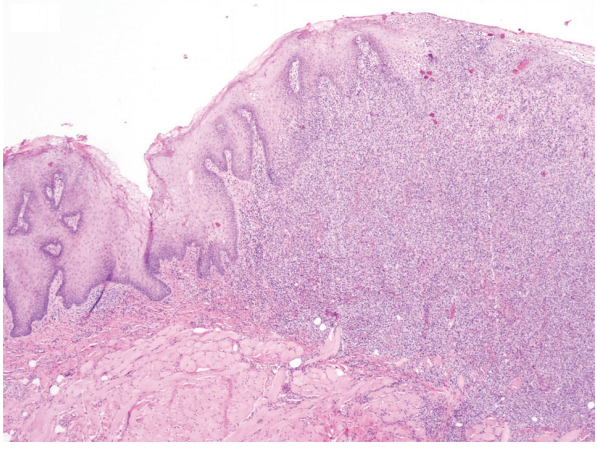

(a)

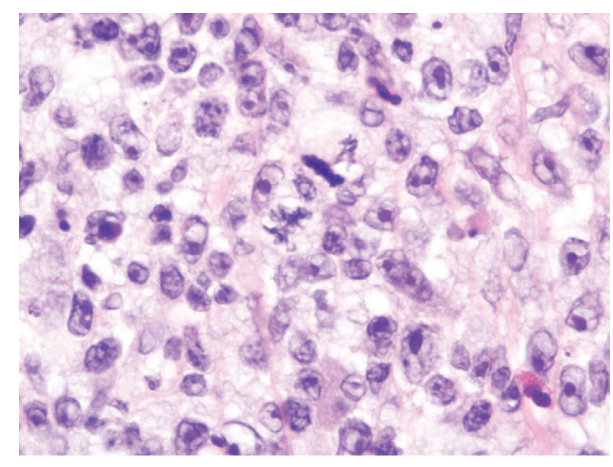

(b)

Figure 2: (a) Fungating lesion of the tongue shows a dense lymphoid infiltrate lined by the squamous epithelium of the oral mucosa. The infiltrate permeates into underlying skeletal muscle of tongue. Hematoxylin and eosin, $\times 40$. (b) The infiltrate is composed of large cells with vesicular nuclei and prominent nucleoli. Atypical mitoses are also observed. Hematoxylin and eosin, $\times 1000$.

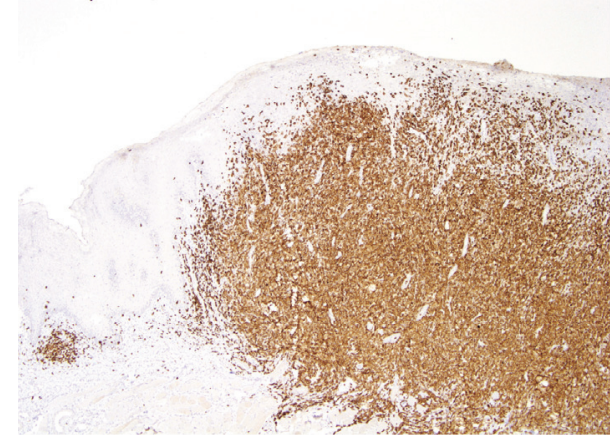

(a)

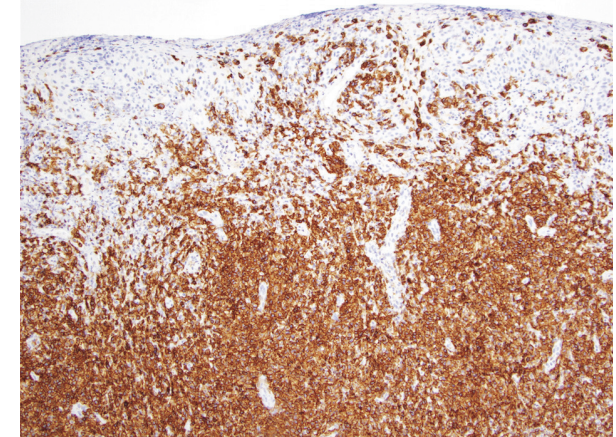

(b)

FIGURE 3: Immunohistochemistry shows that the large neoplastic cells are positive for CD3 (a) and CD30 (b). Immunohistochemistry with hematoxylin counterstain; $\times 40$ (a) and $\times 100$ (b).

MF is classically divided into three progressive, often overlapping, stages: patch, plaque, and tumor. Clinically and histopathologically, patch stage MF is commonly misdiagnosed as psoriasis. Lesions appear erythematous and sometimes scaly usually responding to topical steroids, the mainstay treatment [9]. Microscopically, there is nonspecific inflammatory infiltrate. Atypical cells are not readily identified.

During the plaque and tumor stages, lesions present a much more characteristic histologic picture. There are a dense polymorphous infiltrate and characteristic epidermotropism. Malignant cells called Sezary cells may be seen in the peripheral blood and subsequently may spread to lymph nodes. Sezary cells can be identified in peripheral blood by flow cytometry immunophenotype [10]. Treatments are often directed systemically with medicines such as bexarotene, a vitamin A derivative. In our experience, lesions respond well to local electron beam radiation.

To our knowledge, there are 42 reported cases of oral MF (Table 2). At presentation of oral MF, the age ranged from 36 to 81 years, with a median of 64 . Forty percent were women and $60 \%$ were men. Skin involvement universally preceded oral involvement with the exception of two cases ranging from 6 months to 20 years, with a median of 4 years.

At time of oral lesion diagnosis, $33 \%$ of patients had stage IB disease or lower and $11 \%$ had no active cutaneous disease. Most commonly, patients presented with oral lesions on the palate $(n=21)$ and/or tongue $(n=20)$, which is consistent with the literature $[8,11-19]$. Sixty-one percent had multiple sites of oral involvement. Of the lesions identified, there were 12 tumor, 11 plaque, and 3 patch.

Our patient is remarkable in that he is in complete remission seven years after onset of oral lesion, which defies the median time of one year from diagnosis of oral lesion to death. Further, our patient had large cell transformation, which carries additional poor prognosis [20]. At the time of oral lesion development, no lymphadenopathy was present whereas in many of the reported cases, oral lesions occurred mostly in advanced stages of the disease.

\section{Competing Interests}

The authors declare that they have no competing interests. 


\section{References}

[1] C. S. Ahn, A. ALSayyah, and O. P. Sangüeza, "Mycosis fungoides: an updated review of clinicopathologic variants," American Journal of Dermatopathology, vol. 36, no. 12, pp. 933951, 2014.

[2] V. D. Criscione and M. A. Weinstock, "Incidence of cutaneous T-cell lymphoma in the United States, 1973-2002," Archives of Dermatology, vol. 143, no. 7, pp. 854-859, 2007.

[3] G. Burg, "Systemic involvement in mycosis fungoides," Clinics in Dermatology, vol. 33, no. 5, pp. 563-571, 2015.

[4] E. H. Epstein, D. L. Levin, J. D. Croft, and M. A. Lutzner, "Mycosis fungoides: survival, prognostic features, response to therapy, and autopsy findings," Medicine, vol. 51, no. 1, pp. 61$72,1972$.

[5] E. G. de la Fuente, J. L. Rodriguez-Peralto, P. L. Ortiz, N. Barrientos, F. Vanaclocha, and L. Iglesias, "Oral involvement in mycosis fungoides: report of two cases and a literature review," Acta Dermato-Venereologica, vol. 80, no. 4, pp. 299-301, 2000.

[6] D. Jones, F. Vega, A. H. Sarris, and L. J. Medeiros, "CD4- CD8'double-negative' cutaneous T-cell lymphomas share common histologic features and an aggressive clinical course," American Journal of Surgical Pathology, vol. 26, no. 2, pp. 225-231, 2002.

[7] E. E. Kasha Jr. and C. M. Parker, "Oral manifestations of cutaneous T cell lymphoma," International Journal of Dermatology, vol. 29 , no. 4 , pp. 275-280, 1990.

[8] M. J. Quarterman, J. L. Lesher Jr., L. S. Davis, C. G. Pantazis, and S. Mullins, "Rapidly progressive CD8-positive cutaneous T-cell lymphoma with tongue involvement," The American Journal of Dermatopathology, vol. 17, no. 3, pp. 287-291, 1995.

[9] R. A. Wilcox, "Cutaneous T-cell lymphoma: 2016 update on diagnosis, risk-stratification, and management," American Journal of Hematology, vol. 91, no. 1, pp. 151-165, 2016.

[10] S. I. Jawed, P. L. Myskowski, S. Horwitz, A. Moskowitz, and C. Querfeld, "Primary cutaneous T-cell lymphoma (mycosis fungoides and Sezary syndrome): part I. Diagnosis: clinical and histopathologic features and new molecular and biologic markers," Journal of the American Academy of Dermatology, vol. 70, no. 2, pp. 205. el-205.e16, 2014.

[11] D. D. Damm, D. K. White, M. L. Cibull, J. F. Drummond, and J. R. Cramer, "Mycosis fungoides: initial diagnosis via palatal biopsy with discussion of diagnostic advantages of plastic embedding," Oral Surgery, Oral Medicine, Oral Pathology, vol. 58, no. 4, pp. 413-419, 1984.

[12] G. E. Evans and K. L. Dalziel, "Mycosis fungoides with oral involvement. A case report and literature review," International Journal of Oral \& Maxillofacial Surgery, vol. 16, no. 5, pp. 634637, 1987.

[13] S. M. Goldsmith, B. L. Seo, R. Kumara De Silva, P. Parachuru, A. M. Rich, and G. J. Seymour, "Oral mycosis fungoides: report with immune profile," Oral Surgery, Oral Medicine, Oral Pathology and Oral Radiology, vol. 118, no. 2, pp. e48-e52, 2014.

[14] M. Harman, S. Akdeniz, A. Arslan, and S. Köyoğlu, "Mycosis fungoides with involvement of the oral cavity", Journal of the European Academy of Dermatology and Venereology, vol. 10, no. 3, pp. 253-256, 1998.

[15] G. C. Laskaris, G. D. Nicolis, and J. P. Capetanakis, "Mycosis fungoides with oral manifestations," Oral Surgery, Oral Medicine, Oral Pathology, vol. 46, no. 1, pp. 40-42, 1978.

[16] M. Luigetti, A. Cianfoni, E. Scarano et al., "Mycosis fungoides as a cause of severe obstructive sleep apnea," Internal Medicine, vol. 50, no. 16, pp. 1753-1755, 2011.
[17] M. Postorino, L. Pupo, I. Provenzano et al., "A case of oral mycosis fungoides successfully treated by combination of alemtuzumab and chemotherapy," Annals of Hematology, vol. 95, no. 1, pp. 153-154, 2016.

[18] S. Wahie, H. H. Lucraft, C. Hartley, D. S. Milne, V. Prabhu, and P. M. Farr, "Oropharyngeal mycosis fungoides [5]," Clinical and Experimental Dermatology, vol. 31, no. 6, pp. 821-822, 2006.

[19] J. M. Wright Jr., B. A. Balciunas, and J. H. Muus, "Mycosis fungoides with oral manifestations. Report of a case and review of the literature," Oral Surgery, Oral Medicine, Oral Pathology, vol. 51, no. 1, pp. 24-31, 1981.

[20] S. I. Jawed, P. L. Myskowski, S. Horwitz, A. Moskowitz, and C. Querfeld, "Primary cutaneous T-cell lymphoma (mycosis fungoides and Sézary syndrome): part II. Prognosis, management, and future directions," Journal of the American Academy of Dermatology, vol. 70, no. 2, pp. 223.el-223.e17, 2014. 


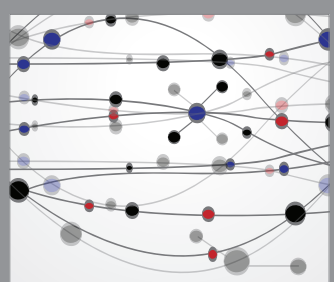

The Scientific World Journal
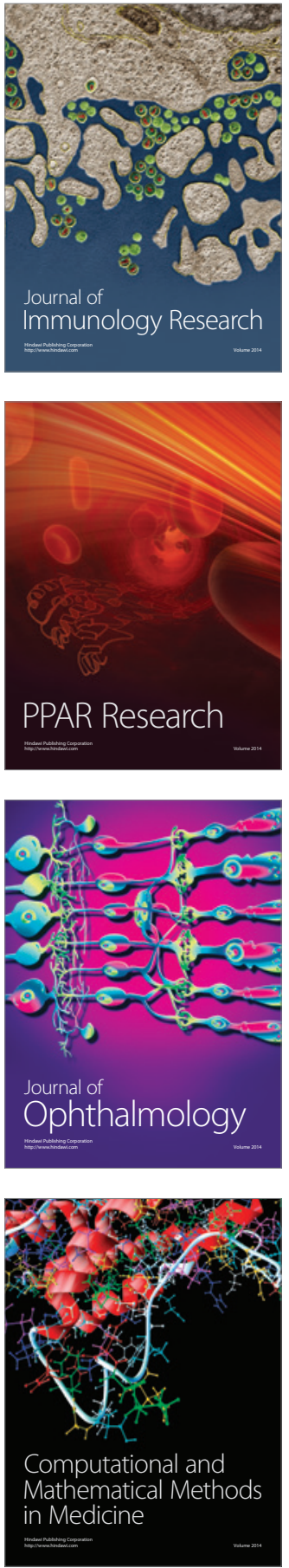

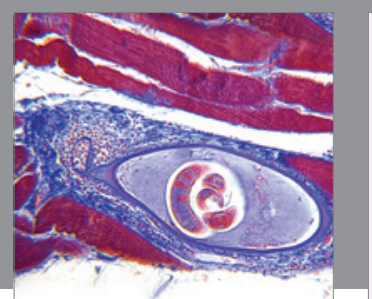

Gastroenterology Research and Practice

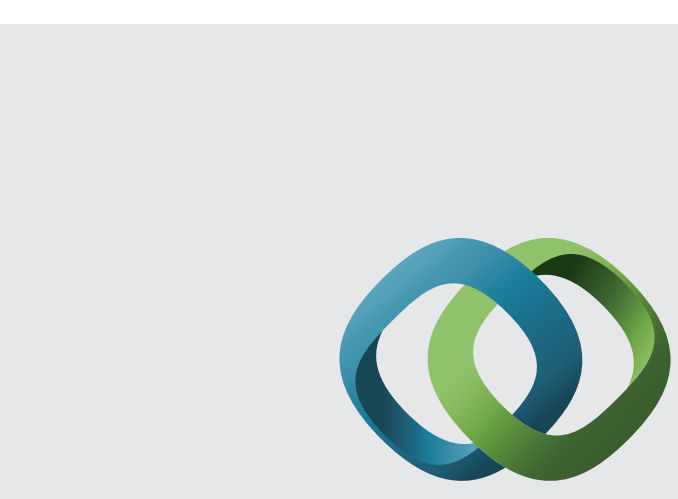

\section{Hindawi}

Submit your manuscripts at

http://www.hindawi.com
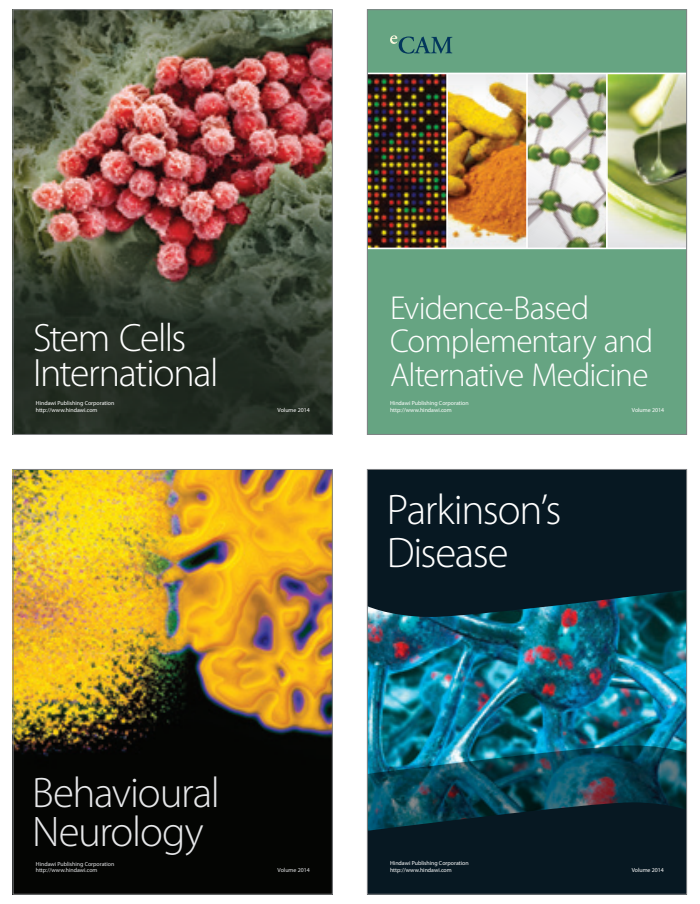
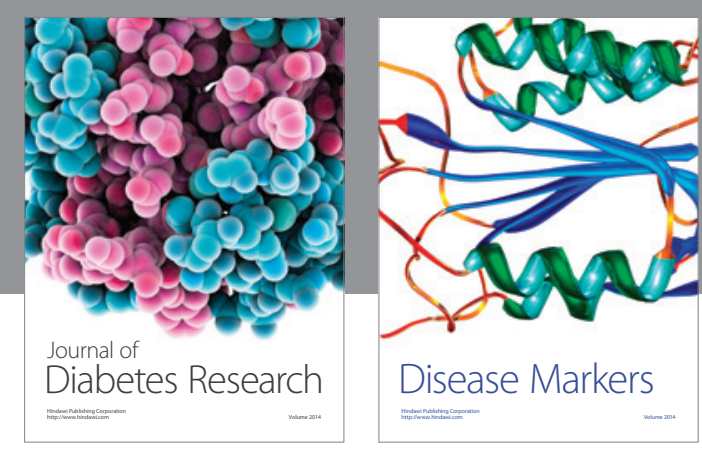

Disease Markers
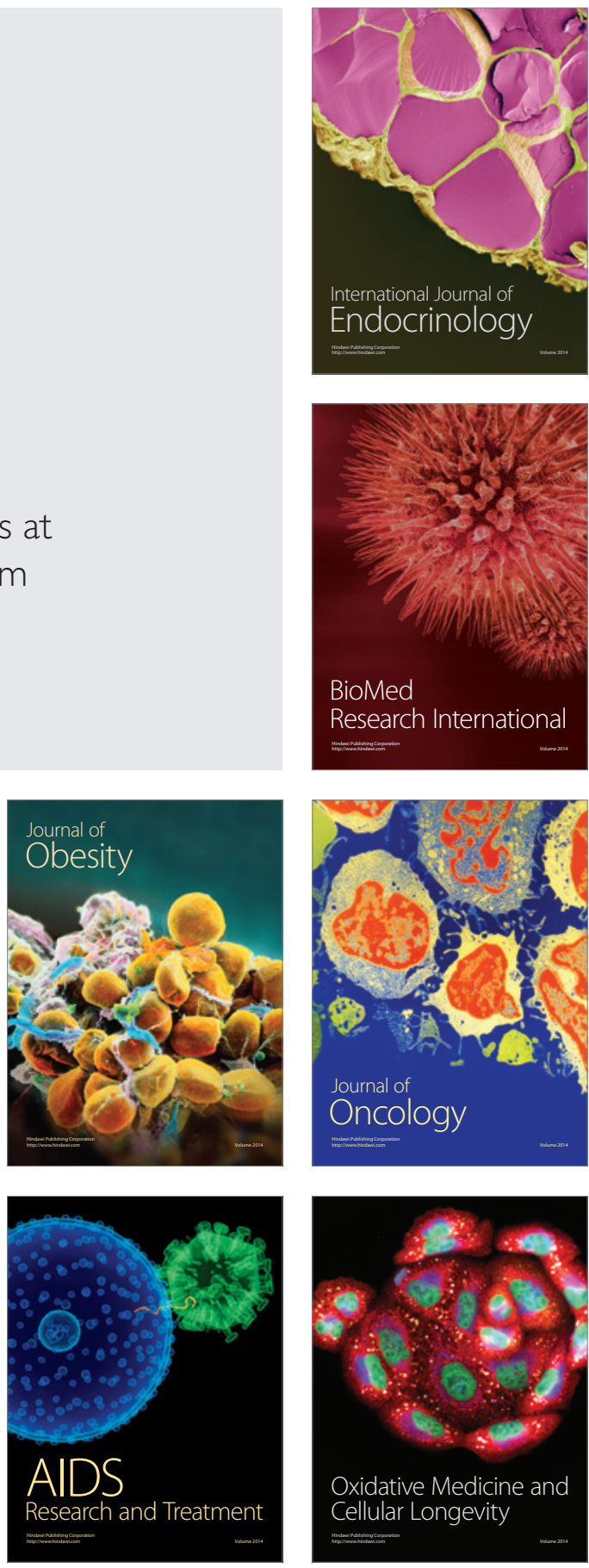